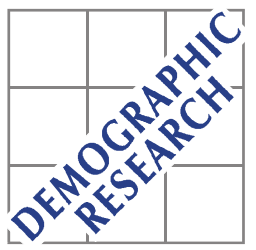

Demographic Research a free, expedited, online journal of peer-reviewed research and commentary in the population sciences published by the Max Planck Institute for Demographic Research Konrad-Zuse Str. 1, D-18057 Rostock · GERMANY www.demographic-research.org

DEMOGRAPHIC RESEARCH

VOLUME 25, ARTICLE 28, PAGES 869-902 PUBLISHED 21 DECEMBER 2011

http://www.demographic-research.org/Volumes/Vol25/28/

DOI: $10.4054 /$ DemRes.2011.25.28

Research Article

\title{
An inquiry into the uneven distribution of women's HIV infection in rural Malawi
}

\section{Michelle Poulin}

\section{Adamson S. Muula}

(C) 2011 Michelle Poulin \& Adamson S. Muula.

This open-access work is published under the terms of the Creative Commons Attribution NonCommercial License 2.0 Germany, which permits use, reproduction \& distribution in any medium for non-commercial purposes, provided the original author(s) and source are given credit.

See http:// creativecommons.org/licenses/by-nc/2.0/del 


\section{Table of Contents}

$\begin{array}{lll}1 & \text { Introduction } & 870\end{array}$

$2 \quad$ Background and setting $\quad 871$

2.1 Marriage and HIV and AIDS in sub-Saharan Africa 873

2.2 Migrating men and HIV and AIDS in sub-Saharan Africa $\quad 874$

2.3 Women's HIV risk and male circumcision $\quad 875$

$\begin{array}{lll}2.4 & \text { The current study } & 875\end{array}$

$3 \quad$ Methods and data $\quad 876$

3.1 Dependent variable $\quad 877$

$\begin{array}{lll}3.2 & \text { Independent variables } & 877\end{array}$

$\begin{array}{lll}3.3 & \text { Controls } & 878\end{array}$

$\begin{array}{lll}3.4 & \text { Missing data } & 878\end{array}$

$\begin{array}{lll}3.5 & \text { Analytic approach } & 879\end{array}$

$4 \quad$ Results $\quad 881$

$5 \quad$ Discussion and conclusions $\quad 886$

6 Acknowledgments $\quad 891$

$\begin{array}{ll}\text { References } & 892\end{array}$ 


\title{
An inquiry into the uneven distribution of women's HIV infection in rural Malawi
}

\author{
Michelle Poulin ${ }^{1}$ \\ Adamson S. Muula ${ }^{2}$
}

\begin{abstract}
Ecological comparisons in sub-Saharan Africa show that HIV prevalence is lower where men are generally circumcised than where they are not. Randomized controlled trials have found a 50-60\% reduction in HIV acquisition for newly circumcised men. Yet in Malawi, HIV prevalence is highest in several districts in the Southern Region, where men are commonly circumcised. We draw upon a population-based sample of ever-married women to explore this unexpected finding. Our data show that in the southern district of Balaka, women with circumcised spouses have a lower probability of HIV infection compared to those with uncircumcised spouses. However, the strength of this effect is conditioned by specific marital histories: among women with circumcised spouses, those with multiple marriages and an absence of spousal coresidence have a higher probability of HIV infection than do those married once and those who have never lived apart from their spouses. The history of marital turnover and female-headed households among the ethnic groups of Balaka offer insight into the district's elevated HIV levels.
\end{abstract}

\footnotetext{
${ }^{1}$ Corresponding author. Assistant Professor, Department of Sociology, 1155 Union Circle \#311157, University of North Texas, Denton, TX, USA, 76203-1157. E-mail: Michelle.Poulin@unt.edu.

${ }^{2}$ Department of Community Health, University of Malawi, College of Medicine, Blantyre, Malawi. E-mail: muula@email.unc.edu.
} 


\section{Introduction}

A trio of randomized controlled trials conducted in South Africa, Kenya, and Uganda during the last decade found male circumcision to reduce a man's risk of acquiring HIV from an infected partner by 50\% to 60\% (Auvert et al. 2005; Bailey et al. 2007; Gray et al. 2007). These trials established male circumcision as one of the few procedures known to curb infection with HIV (see also Doyle et al. 2010). ${ }^{3}$ In response, donor organizations such as the President's Emergency Plan for AIDS Relief (PEPFAR), the Global Fund, and the Bill and Melinda Gates Foundation have provided funding to numerous other countries in sub-Saharan Africa adopting male circumcision policies (Dickson 2010; WHO/UNAIDS 2010).

One country that has hesitated in accepting male circumcision as an effective intervention to prevent HIV transmission is Malawi. Country officials claim that no "scientific evidence" has shown that the procedure effectively curbs the epidemic (Washington Post 2010). On the face of it, such claims appear logical: the most recent Malawi Demographic and Health Survey (MDHS) found that a greater percentage of circumcised $(13.2 \%)$ than uncircumcised $(9.5 \%)$ men were HIV positive, leading the authors of the 2004 Final Report to conclude that "the relationship between HIV prevalence and circumcision status is not in the expected direction" (MDHS 2005, p. 235). Population-based data from the 2004 wave of the Malawi Diffusion and Ideational Change Project (MDICP) show a similar correlation. HIV prevalence was found to be highest in the southern district of Balaka, at 9.6\%, which was surprising given that $83 \%$ of the sample of men affirmed that they were circumcised. While circumcision is rarely practiced in the districts of Mchinji in the Central Region and Rumphi in the Northern Region, HIV prevalence is lower in these two settings (at 7.8\% and $5.1 \%$, respectively) than in the South (Table 1).

This study aims to better understand this seeming paradox. Since male circumcision greatly reduces a man's risk of new infection, and in Balaka District men commonly circumcise, other sources of infection must contribute to the district's relatively higher levels of HIV. One of Southern Malawi's striking demographic features is the regular occurrence of marital turnover, attributable to specific forms of social organization associated with matrilineality and matrilocality (Kaler 2001; Mitchell 1951; Mitchell 1956; Peters 1997; Vaughan 1983; see Ferguson 1999 for Zambia). In contemporary Balaka about half of all marriages dissolve within 20 years

\footnotetext{
${ }^{3}$ Another highly effective prevention is antiretroviral prophylaxis, used to prevent HIV transmission from infected mothers to their infant children (e.g., Arrive et al. 2007; Boeke and Jackson 2008; Taha et al. 2003). Condom use also effectively blocks the transmission of HIV between sero-discordant sexual partners, although many committed couples do not want to use condoms at every sexual encounter, or at all (Chimbiri 2007; Tavory and Swidler 2009).
} 
and, upon divorce, women and men remarry quickly, making these rates among the highest in all of Africa (Reniers 2003). This paper therefore considers, as a backdrop, whether Balaka-specific marital practices contribute to the district's high HIV levels.

In this study we direct our attention to HIV infection among women, to whether and how key aspects of women's marital lives reduce the likelihood of HIV infection or, alternatively, are consequential in other ways. As a part of this, the paper examines whether spousal circumcision is related to a lower probability of being HIV positive. Several studies have investigated the direct and indirect effects of male circumcision on a woman's HIV risk in sub-Saharan settings, but the results have been conflicting, with some finding a protective effect while others not (Allen et al. 1991; Baeten et al. 2010; Gray et al. 2000; Hunter et al. 1994; Kapiga et al. 1998; Turner et al. 2007; Wawer et al. 2009). We examine how, within Malawi's southern district of Balaka, key characteristics of a woman's married life (including the number of times she has been married, whether she has ever resided apart from her spouse while married, and whether she has ever been married to an uncircumcised spouse) may be associated with her probability of HIV infection. Our data strongly suggest that any claims of no "scientific evidence" for the protective effect of male circumcision in Malawi is based on an ecological fallacy, as our sub-region analyses - with their focus on women of Balaka specifically - reveal a more complicated scenario.

\section{Background and setting}

Malawi is a small landlocked country located in the south-eastern corner of sub-Saharan Africa. With 15 million people, it is one of the more densely populated nations on the continent. Although Malawi's rate of urbanization has increased since its independence from Britain in 1964, it has been generally modest compared to rates in neighboring countries like Zambia. Most people continue to reside in rural villages, earning livelihoods as subsistence farmers. Its economy is based in cash, which is necessary to purchase essentials such as cooking oil and clothing, and to pay fees for public transportation and for children's schooling. With formal employment scarce, men travel regularly to Malawi's cities in search of cash-paying jobs as night watchmen or gardentenders, or of entrepreneurial opportunities as small traders. Urban migration is often to squatter settlements and occurs over extended durations, but emotional attachments to "home," for many of these men, remain located in the rural village (Englund 2002a). 
Table 1: Male circumcision and HIV status by region, 2004

\begin{tabular}{lcccccccccc}
\hline & \multicolumn{2}{c}{$\begin{array}{c}\text { Women with } \\
\text { circumcised spouses }\end{array}$} & \multicolumn{2}{c}{ circumcised } & \multicolumn{2}{c}{ Women HIV + } & Men HIV + & \multicolumn{2}{c}{ Total HIV + } \\
\hline District: & $\%$ & $\mathbf{N}$ & $\%$ & $\mathbf{N}$ & $\%$ & $\mathbf{N}$ & $\%$ & $\mathbf{N}$ & $\%$ & $\mathbf{N}$ \\
Balaka & 81.95 & 543 & 82.85 & 274 & 10.43 & 489 & 8.64 & 359 & 9.61 & 853 \\
Rumphi & 2.81 & 462 & 5.35 & 318 & 5.5 & 436 & 7.26 & 303 & 5.06 & 771 \\
Mchinji & 6.46 & 495 & 5.39 & 371 & 8.35 & 395 & 4.62 & 325 & 7.85 & 701 \\
\hline Number of Observations & 1500 & & 963 & & 1320 & & 987 & & 2325 \\
\hline
\end{tabular}

Note: Women's spousal circumcision status comes from marital history data from the MDICP3 (2004) wave, and refers to current, or, if divorced or widowed, most recent spouse.

The MDICP's sample of respondents comes from three districts across three administrative regions: Balaka in the Southern Region, Mchinji in the Central Region, and Rumphi in the Northern Region. The three largest of Malawi's dozen ethnic groups roughly map onto the three regions, both politically and in the popular imagination. In Balaka, the Yao ethnic group are predominant, in Mchinji, the Chewa are predominant, and in Rumphi, most Malawians are of the Tumbuka-speaking ethnic group. Male Yao get circumcised during initiation ceremonies as part of ethnic and religious coming-ofage practices. Most women and men in Mchinji and in Rumphi practice a form of Christianity, and the vast majority of men in these two districts do not get circumcised. Socioeconomic circumstances also differ across region: of the three districts, Balaka is the poorest and women and men attain low levels of education. Fully half of the MDICP sample of women living in Balaka had never attended school, compared to $29 \%$ in Mchinji, and just 2\% in Rumphi, reasons for which are rooted in the Livingstonia Protestant missionary emphasis on schooling in Rumphi that missionary agendas elsewhere in the country lacked, including the dominant Catholic missionary (Vail and White 1985; Table 2).

Forms of social organization that hinge upon marriage and family differ across Malawi, although lineage customs have never followed distinct, neat lines, and an increasing number of young Malawians now establish new households irrespective of lineage customs (Poulin 2011). In Balaka, however, family and social life are reproduced across generations mainly through matrilineality and matrilocality, so that integral resources of kin, land, and other forms of wealth are inherited through the matriline (Weinreb 2002), and men tend to move to wives' compounds following marriage. In such societies, bonds of kinship tend to be stronger than bonds of marriage and divorce is common (Ferguson 1999; Kaler 2001; Mitchell 1951; Peters 1997; Vaughan 1983). Two-thirds of all first marriages end in divorce in contemporary 
Balaka, far higher than the roughly one-third of first marriages in Mchinji and the onequarter in Rumphi (Reniers 2003).

\subsection{Marriage and HIV and AIDS in sub-Saharan Africa}

A body of literature focuses on the contributions of marriage and long-term unions both to HIV risk for individuals and HIV prevalence within larger communities (e.g., Boerma et al. 2003; Boileau et al. 2009; Chomba et al. 2008; Clark 2004; Glynn et al. 2001a; Glynn et al. 2003; Gregson et al. 2002; Kelly et al. 2003; Painter et al. 2007; Trask et al. 2002). Marriage may present epidemiological risk through a regularity of sexual intercourse, accompanied by very little (if any) condom use (Ali et al. 2004; Chimbiri 2007; Tavory and Swidler 2009). This is problematic if, for instance, one spouse is infected at the time of marriage, or if one or both spouses have sex outside of marriage, and subsequently bring HIV into the marital union (Dunkle et al. 2008; Parikh 2007; Smith 2007).

Some studies emphasize the unions leading up to marriage, or those following dissolution due either to divorce or death (Kumwenda et al., 2008; Quigley et al. 2000; Reniers 2008). In rural Zimbabwe, for example, Lopman et al. (2009) find that an estimated $6 \%-17 \%$ of all new infections occur through the sexual activity of widows and widowers. Bongaarts (2007) argues that the search for a suitable spouse prior to marriage holds greater risk than does the marriage itself, a phenomenon akin to what Magruder (2010) has called marital "shopping," claimed to occur frequently enough to have generated and now sustain the epidemic in South Africa.

While these studies begin to improve epidemiological understanding of how marriage relates to HIV and AIDS in sub-Saharan Africa, a decidedly sociological approach to this relationship is far less common - clear exceptions notwithstanding (Hirsch et al. 2009; Thornton 2008). How marriage is practiced varies widely across the subcontinent, such as in the timing of first marriage, or in how common marriage is in a community or society, or in the regularlity of divorce and remarriage. In parts of South Africa, Botswana, and urban Nairobi, for example, people delay marriage until their late 20 s and early 30 s, opting first to cohabit, or to forego marriage altogether. In Malawi marriage is revered: nearly all women and men marry at least once, and marriage occurs early in life. The most recent round of data from the DHS show that $96 \%$ of all women aged 25-29 have married by age 25 , and nearly all (99.1\%) women and men have married at least once by ages 30 and 40, respectively. The median age at first marriage is 18.0 years for women and 22.9 years for men (MDHS 2005). ${ }^{4}$ How marriage differs

${ }^{4}$ Couples consider themselves married upon co-residence, even in the absence of a ceremony, or prior to the requisite gift exchange (Clark et al. 2009). 
across social space may matter for an individual's risk of contracting HIV infection. Marrying an older man, for instance, or marrying for a second time, could place a woman in a new sexual network. In addition, acquiring additional partners provides differential risk depending on population HIV prevalence.

Marriage patterns across social space also have implications for the production and containment of HIV epidemics. The way a population marries or does not marry will correspond to distinct configurations of sexual networks; the diffusion of disease depends on the timing and content of network structures, and not (only) on the accumulation of sexual partners for any one individual (Kretzschmar and Morris 1996; Morris and Kretzschmar 2000; Morris et al. 2009; Salathé and Jones 2010; Watts and May 1992). For these reasons we conceive of marriage as something understood and practiced by a group of people, which we believe adds a needed depth to existing research on marriage and HIV (Boerma et al. 2003; Boerma and Weir 2005; Caraël and Holmes 2001).

\subsection{Migrating men and HIV and AIDS in sub-Saharan Africa}

Although a partner may bring HIV into a marriage from a prior relationship or sexual encounter, an absence of spousal co-residence (due to labor migration, for example) increases the chances that one or both spouses acquire another partner (Hirsch et al. 2009). Such overlaps in sexual activity with more than one partner permit an easier transmission of the virus through the human vector (Moody 2002; Morris and Kretzschmar 1995, 1997). In earlier phases of AIDS epidemics, patterns of circular migration contributed to the spread of HIV in a population. Migrating men became infected with HIV while away, bringing the virus into local regions by infecting their non-migrant wives or primary sexual partners upon returning home and before leaving again (e.g., Boerma et al. 2002; Coffee et al. 2007; Glynn et al. 2001b; Lurie et al. 2003a; Lurie 2005; Zuma et al. 2005). The situation becomes more complicated during the epidemic's later stages. Should the virus gain a foothold in a population, the influence of returning migrants may matter less in perpetuating its spread (Lurie 2006).

Presumably, with spouses away, local female partners have always formed their own sexual relationships, and recent evidence suggests that it may be women, and not men, who bring HIV into their more-committed, longer-term unions. Helleringer, Kohler, and Chimbiri (2007) show that, among women on Likoma Island on Lake Malawi who have an "external" (non-local) sexual partner, those whose sexual partners were temporary visitors to local areas had a higher relative risk of HIV, compared to other "out-migrant" types. De Walque (2007) shows that between $30 \%$ and $40 \%$ of sero-discordant married couples have wives who are HIV-positive, consistent with 
other studies finding that a number of wives, but not their husbands, are HIV positive (Chomba et al. 2008; Lurie et al. 2003b). ${ }^{5}$ In Malawi, the Southern Region is the poorest and fares worst on most social and economic indicators (World Bank and Government of Malawi 2007), which likely leads to more out-migration of men and expands the sexual networks - and consequently the HIV risk - of both migrants and their female partners.

\subsection{Women's HIV risk and male circumcision}

Two studies have found that the circumcision status of a woman's primary sexual partner is not associated with her risk of HIV infection (Allen et al. 1991; Turner et al. 2007); two others have found that male circumcision is associated with reduced risk (Kapiga et al. 1998; Hunter et al. 1994). Three studies tested for the direct effects of circumcision on a woman's probability of contracting HIV. Gray et al. (2000) found that female partners of circumcised HIV-infected men had a lower probability of acquiring HIV, but Wawer et al. (2009) found that HIV incidence was not statistically different for women whose HIV-infected partners underwent circumcision compared to those whose partners remained uncircumcised. Baeten et al. (2010), drawing from a sample of 1,096 HIV-positive men and HIV-negative female partners, identify a "nonstatistically significant decreased risk of HIV-1 transmission from circumcised HIV-1infected men to their female partners, compared with couples with uncircumcised HIV1-infected men" (p. 5).

\subsection{The current study}

In the analyses that follow we describe the social conditions associated with mortality risk across rural Malawi. We employ an analytic approach that examines alternate model specifications of key relationships within and across districts. Our specific research questions are twofold. First, what are the relative contributions of spousal circumcision and marital histories, including multiple marriages and absence of spousal co-residence, on women's HIV status in rural Malawi? Second, how might these relations differ at the sub-region level? We ground our empirical analyses within our knowledge of Malawian social and economic life to examine how contemporary AIDS epidemics are distributed across place (Boerma et al. 2003; Caraël and Holmes 2001;

\footnotetext{
${ }^{5}$ Most of these studies use cross-sectional data and therefore cannot determine whether an HIV-positive wife brought HIV into the union from a prior marriage.
} 
Karim 2009; Gillespie et al. 2007; Tanser et al. 2009; for historical accounts of AIDS in Africa, see Iliffe 2006; Thornton 2008).

\section{Methods and data}

Our analyses come from a sample of ever-married women from the Malawi Diffusion and Ideational Change Project (MDICP). In 1998 (MDICP1) the project conducted its first round of data collection from 1,541 ever-married women and 1,065 men in Balaka, Rumphi, and Mchinji. The MDICP was designed to investigate the influence of social networks on behavior related to AIDS and family planning, and has conducted subsequent rounds since its initial wave in 1998. In 2004 (MDICP3) the MDICP offered respondents the opportunity to participate in HIV counseling and testing by trained nurses using Ora-Sure ${ }^{\mathrm{TM}}$ Oral swabs. The same fraction of women and men consented to HIV testing $(91 \%){ }^{6}$ A follow-up round of testing was included in 2006 (MDICP4), in which $92 \%$ of the sample accepted an HIV test, a percentage nearly identical to those accepting a test in 2004 . $^{7}$

These analyses include the sample of ever-married women based on two criteria. First, female respondents had to have been tested for HIV in either 2004 or 2006. A total of 1,440 ever-married women consented to HIV testing in these years. Although we cannot measure the incidence of HIV infection because of the relatively small number of sero-conversions across waves, we improve statistical power by pooling HIV status from 2004 and 2006. To account for respondents who were tested twice, once in 2004 and once in 2006 ( $\mathrm{n}=925$, or 67.2\%), all models include a 'tested twice' control dummy. Second, women had to have participated in the survey in 2004, the year when extensive information on marital and sexual histories was collected, including a question that asked women about the circumcision status of their current and former spouses, if any. Of those who were tested in either 2004 or 2006, 1,418 participated in the survey in $2004 .^{8}$

\footnotetext{
${ }^{6}$ Approval for HIV testing and counseling was received from the Institutional Review Board at the University of Pennsylvania and the Research and Ethics Committee at the Malawi College of Medicine.

${ }^{7}$ In 2004 the specimens were analyzed at the University of North Carolina Project's laboratory in the Malawian capital city of Lilongwe using enzyme-linked immunosorbent assays (ELISA) and confirmatory Western blot tests for HIV, and Roche PCR for STIs (Bignami-Van Assche et al. 2004; Obare et al. 2009; Thornton 2008). In 2006, HIV testing was done by certified volunteer counseling and testing (VCT) counselors in respondents' homes using finger-prick rapid testing (parallel Determine ${ }^{\mathrm{TM}}$ and UniGold HIV tests). Respondents were given the option to receive their test results either in their homes or at mobile clinics (tents); virtually all respondents chose to receive the results in their homes.

${ }^{8}$ In 2004 the MDICP added a panel of 15-24-year-old adolescents and young women and men to the 1998 main sample of ever-married individuals. The 2004 adolescent sample yielded completed interviews with 718 female (256 never-married) and 767 male (409 never-married) respondents. New spouses of those marrying
} 


\subsection{Dependent variable}

Our dependent variable is women's HIV status. Women who are HIV positive are scored "1;" those who are not are scored " $0 . "$

\subsection{Independent variables}

Based on the literature outlined above, we consider three key independent variables as potential contributors to HIV infection and distribution: (1) marriages to circumcised spouses only, as opposed to at least one marriage to an uncircumcised spouse; (2) having been married at least twice, or "multiple marriages;" and (3) having experienced an absence of spousal co-residence. Spousal circumcision is measured using the MDICP survey question that asked women, "As you know, some men have become circumcised. What about your spouse, has he ever been circumcised?" This question was asked about each spouse, beginning with the current or most recent one and for each previous spouse, if any. "Multiple marriages" is binary and scores women who have been married more than once as "1," with " 0 " assigned to women with one marriage only. Women who were divorced or widowed from their first marriage and had yet to remarry are also assigned 0 . An "absence of spousal co-residence" measures whether a woman's spouse (current or former) has ever lived elsewhere (outside of her household), and is also binary.

Because these measures come from retrospective reporting, they may be biased due to recall error, or to intentional omission of marriages, such as those short in duration. We consider these data advantageous nevertheless - many population-based surveys, such as the DHS, are unable to collect such detailed information given the constraints their modules impose (Reniers 2008).

by 2006 were added to the MDICP sample. As these new wives were not interviewed in 2004 we were not able to include them in these analyses; similarly, ever-married women temporarily absent in 2004 were also not included. These two groups total $\mathrm{N}=308$. Although they differ by age from the included sample of women, they do not differ by region of the country and by whether they have had an uncircumcised spouse.

${ }^{9}$ In Balaka $89 \%$ of Yao women had a history of marriage to circumcised spouses only, reflecting the relatively low degree of ethnic heterogamy among Yao women compared to Malawi's other ethnic groups in Balaka. $21 \%$ of Yao women in the sample had been ever-married to a non-Yao spouse, compared to the $74.5 \%$ of Chewa who had ever-married a spouse from a tribe other than Chewa. Within each district, the fractions of men who reported being circumcised were remarkably similar to the fractions of women who reported marriage to circumcised spouses (Table 1). The near-match lends evidence of the validity of women's reports. 


\subsection{Controls}

Many studies have identified correlations between education, wealth, and HIV risk, and we control for both (Fortson 2008; Fylkesnes et al. 1997; Gregson et al. 2001; Hargreaves et al. 2007; Hargreaves and Glynn 2002; Mishra et al. 2007; Shelton et al. 2005). ${ }^{10}$ We use a dichotomous measure of education, scoring women as 1 if they completed three years of education or more, and 0 otherwise. The measure for household wealth is based on a five-point household asset index that sums whether someone in the household owns a bicycle, a radio, a paraffin lamp, a bed, or an oxcart. This index is subsequently divided into wealth tertiles. The upper tertile is scored 1 and the bottom two tertiles are scored 0 . Multiple measures of wealth and education were tested in all models, none of which led to substantively different results from the results presented in the final models. ${ }^{11}$ Age and age-squared are used in all models to account for the non-linear relation between age and HIV infection.

\subsection{Missing data}

Missing data on all variables are replaced using the ICE user-written multipleimputation procedure in Stata. The imputation model predicts missing values on independent variables with important covariates that are thought to be predictive. We created five plausible values for each missing observation and five parallel data sets for analyses. HIV status is not imputed in the models, so as to avoid unnecessary noise to estimates (von Hippel 2007). The substantive findings of the multivariate analyses are robust using the imputed missing data compared to data that omitted missing values through case-wise deletion. ${ }^{12}$

\footnotetext{
${ }^{10}$ The literature on the relation between SES and HIV is now quite large, with several studies pointing to a positive correlation between the two (e.g., Fortson 2008; Mishra et al. 2007; Poulin and Watkins 2011; Shelton et al., 2005). Some have found a weak, negative correlation between SES and HIV (e.g., Hargreaves et al. 2007; Bärnighausen et al. 2007).

${ }^{11}$ These variations in measures include wealth as a continuous measure, wealth as measured by housing and roofing material, a binary measure of education "completed primary," and education as a continuous measure. ${ }^{12} 22$ women $(.016 \%$ of the sample) who participated in the survey in 2004 and were tested for HIV in either 2004 or in 2006 reported not knowing the circumcision status of any of their male spouses, and for another 20 respondents data on this measure were missing. Although a greater fraction of these women resided in Mchinji and Rumphi than in Balaka, they did not differ across district by age, education, or HIV status. Imputing their values brings the sample size from 1,376 to 1,418 observations $(22+20=42)$. The size of the effects of key predictor variables changed very little across the sample with imputed cases, compared to the sample with cases deleted due to missing or unknown spousal circumcision data (not shown, analyses available from the first author upon request).
} 


\subsection{Analytic approach}

The analytic goals of this research are to describe the associations between marriage histories, male spousal circumcision, and HIV infection among Malawian women, across the country and sub-regionally. Our analyses proceed in two steps.

Using data pooled across region, we first consider to what extent each of the predictor variables tempers the effect of residing in Balaka. We estimate a series of logit models that regresses women's HIV status on Balaka residence, a dummy variable coded 1, and 0 otherwise. Because Rumphi District and Mchinji District exhibit similar characteristics along several dimensions pertinent to the goals of this paper, including the small fraction of men circumcised, we improve statistical power by combining these two regions, and call it "Mchinji \& Rumphi." Predictor variables are grouped together on substantive grounds and added to the model sequentially. This approach enables us to monitor the change in both spousal circumcision and the effect of Balaka residence, relative to the controls for socio-economic measures and marriage characteristics.

Second, we consider whether the strength of the relations between HIV status and the set of covariates depends on region of residence. For example, a second marriage is less risky in a community with a relatively lower HIV prevalence than in a community with a relatively higher HIV prevalence, because marrying for a second time in a place with a relatively higher HIV prevalence increases the chances that the new spouse will be infected with HIV. Pooled data would mask such a distinction, and we therefore estimate models that allow the predictors' effects to vary by region.

Summary statistics for women's socio-demographic and behavioral characteristics in the Balaka, Mchinji, and Rumphi Districts from the 2004 survey wave are presented in Table 2. Over $45 \%$ of Balaka women have been married more than once in their lifetimes, compared to $32 \%$ of women in Mchinji and $24 \%$ of women in Rumphi. Balaka women are significantly more likely to have lived apart from their spouses; a greater percentage of Balaka women have had a spouse who at one point in time resided outside of their home. 
Poulin \& Muula: An inquiry into the uneven distribution of women's HIV infection in rural Malawi

Table 2: Demographic and marriage characteristics by district of country for ever-married women, 2004

Individual Demographics

Mean age, in years

36.15

(12.18)

Education

Never attended school

Mean years of education attended

Wealth

House has a metal roof (vs. thatch)

Wealth index, mean (scale 1-5)

\section{Marriage Characteristics}

Current spouse uncircumcised

Any spouse uncircumcised

Current marital status

\begin{tabular}{|c|c|c|c|c|}
\hline Married & .89 & .91 & .89 & n.s. \\
\hline Separated or divorced & .06 & .06 & .06 & n.s. \\
\hline Widowed & .05 & .03 & .05 & n.s. \\
\hline Married more than once & .45 & .32 & .24 & ** \\
\hline Married more than twice & .15 & .07 & .02 & ** \\
\hline Ever an absence of spousal co-residence & .20 & .14 & .13 & * \\
\hline Number of Observations & 513 & 450 & 455 & \\
\hline
\end{tabular}




\section{Results}

Odds ratios from the pooled models for women's HIV infection, a history of marriage to circumcised spouses only (as compared to those ever-married to an uncircumcised spouse), and Balaka residence are presented in Table 3. Model 1 includes "All spouses circumcised;" "Balaka" is added in Model 2; socio-economic variables are added in Model 3; and marriage history is added in Model 4. All models control for age, agesquared, and a dummy variable for having been tested twice for HIV.

For women with a history of marriages to circumcised spouses only, the odds of being HIV positive do not differ across districts from those women ever-married to an uncircumcised spouse (Model 1). However, once a dummy variable for Balaka residence is included, thus controlling for district, we find a correlation between spousal circumcision and HIV infection. Compared to women ever-married to an uncircumcised spouse, those with circumcised spouses only have half the odds of HIV infection ( $\mathrm{z}=$ 2.17; Model 2). We use predicted probabilities and the delta method to determine whether the differences are statistically significant and present the results in Table 4. Women with circumcised spouses only are predicted to have a probability of HIV infection that is just over half that of women currently or formerly married to an uncircumcised spouse (.049 - .092), significant at the .05 level (Table 4, Panel A, Model 2); socio-economic characteristics do not reduce the difference (Model 3). ${ }^{13}$ The circumcision effect is reduced once multiple marriages and absence of spousal coresidence are added; between women with circumcised spouses only and those evermarried to an uncircumcised spouse, the difference in the predicted probabilities is reduced from .041 to .022 and is no longer significant (Table 3, Model 4; Table 4, Panel A, Model (4)).

Also important is the persistence of the effect 'residing in Balaka.' Net of all other measures displayed in Table 3, Balaka residence remains significant at the .05 level $\left(L R X^{2}=5.93, d f=1, p=.015\right)$, confirming broad differences in HIV levels across districts. The marriage history measures are themselves strongly correlated with HIV infectivity, however, and once added in Model 4, reduce the strength of the Balaka effect

\footnotetext{
${ }^{13}$ As Long (2009) explains, comparing groups in regression models for binary outcomes is complicated by the identification problem inherent in these models: if the amount of residual variation differs between groups the test can lead to incorrect conclusions. Allison (1999) circumvents this problem by assuming that the regression coefficients for some variables across groups are the same. Long (2009) points out that researchers often lack good information about whether this assumption is true, and therefore proposes an approach to test for the equality of means across predicted probabilities, at different values of the independent variables. This technique is unaffected by group differences in residual variation, and does not require assumptions about the equality of regression coefficients for some variables. Comparing predicted probabilities across differing values does require, however, that the researcher knows a priori which values are worth comparing: something we are able to do here.
} 
substantially, just as they reduced the strength of the spousal circumcision effect. ${ }^{14}$ The combined effects of multiple marriages and absence of spousal co-residence are highly significant $\left(L R X^{2}=46.44, d f=2, p=.000\right)$.

Table 3: Logit regression models of women's HIV infection, with spousal circumcision and Balaka residence (odds ratios)

\begin{tabular}{|c|c|c|c|c|}
\hline & (1) & (2) & (3) & (4) \\
\hline \multirow[t]{2}{*}{ Married to circumcised spouse/s only } & 1.294 & $0.532^{\star \star}$ & $0.559^{\star \star}$ & 0.708 \\
\hline & $(1.261)$ & $(-2.170)$ & $(-1.960)$ & $(-1.167)$ \\
\hline \multirow[t]{2}{*}{ Balaka resident } & & $3.083^{* * *}$ & $3.366^{\star \star *}$ & $2.228^{\star \star \star}$ \\
\hline & & $(4.150)$ & $(4.355)$ & $(2.821)$ \\
\hline \multicolumn{5}{|l|}{ Socio-economic characteristics } \\
\hline \multirow[t]{2}{*}{ Completed three years of school } & & & 1.332 & 1.429 \\
\hline & & & $(1.179)$ & $(1.464)$ \\
\hline \multirow[t]{2}{*}{ Upper-third of wealth tertile } & & & 1.065 & 1.261 \\
\hline & & & $(0.294)$ & $(1.038)$ \\
\hline \multicolumn{5}{|l|}{ Marriage history } \\
\hline \multirow[t]{2}{*}{ Been married > once } & & & & $2.734^{* * *}$ \\
\hline & & & & $(4.571)$ \\
\hline \multirow[t]{2}{*}{ Ever an absence of spousal co-residence } & & & & $2.075^{\star * *}$ \\
\hline & & & & (3.647) \\
\hline Observations & 1418 & 1418 & 1418 & 1418 \\
\hline Pseudo R-Square & 0.0529 & 0.0718 & 0.0741 & 0.1215 \\
\hline Log Likelihood & -400.5 & -392.5 & -391.6 & -371.5 \\
\hline
\end{tabular}

Robust $z$ statistics in parentheses

${ }^{* * \star} p<0.01,{ }^{* *} p<0.05$

Notes: All models control for age and age-squared. The outcome variable is being HIV positive, and is derived from pooling HIV statuses from the MDICP's 2004 and 2006 rounds of testing. To control for respondents who were tested twice $(n=925$, or $67.2 \%$ ), a dummy variable "tested twice" $=1$, otherwise 0 , was included in all models. Among those who tested HIV negative in $2004,1.15 \%(n=13)$ had sero-converted when they were tested again in 2006 . The variables "circumcised spouse/s only" and "ever an absence of spousal co-residence" refer to current or former marriages. Respondents ever married to an uncircumcised spouse are coded ' 0 ,' regardless of whether their current spouse is circumcised. Respondents reporting never an absence of spousal co-residence are coded '0.'

${ }^{14}$ Several alternative specifications were tested but did not alter the substantive results reported in Table 3 (i.e., the strength of the main predictor variables including spousal circumcision, Balaka residence, and marriage history measures). These include "general sexual mixing" measures such as age at first sex; had a spouse five or more years older; had non-spousal sex (the number reporting yes for women is less than $2 \%$ of this sample); best friend had an extra-marital partner (as a proxy for a woman's own extra-marital partnership); and number of lifetime partners. On the last variable, number of lifetime partners, alternative ways to measure were tested, including as a count measure, and as dichotomous measures with cut-off points for relatively high number of sexual partners at $80 \%, 85 \%$ and at $90 \%$. Also tested (but yielded inconsequential results) was frequency of sex with spouse. Finally, women's own geographic mobility, as measured by whether a woman was away for one month in the past year, and was away for six months ever in her lifetime, was included in the specifications but was not significant. 
Table 4: Simulation of the probability that a Malawian woman is HIV positive, by spousal circumcision, district, and marriage history

\begin{tabular}{|c|c|c|c|c|c|}
\hline \multirow[t]{2}{*}{$\begin{array}{l}\text { Panel A. By spousal circumcision, across } \\
\text { three districts in three regions. }\end{array}$} & \multicolumn{2}{|c|}{ Probability HIV + } & & \multicolumn{2}{|c|}{$\begin{array}{l}95 \% \mathrm{Cl} \text { for the } \\
\text { Difference }\end{array}$} \\
\hline & $\begin{array}{c}\text { Circumcised } \\
\text { spouses only } \\
(=1)\end{array}$ & $\begin{array}{c}\text { Circumcised } \\
\text { spouses only } \\
(=0)\end{array}$ & Difference & $\begin{array}{l}\text { Lower- } \\
\text { Bound }\end{array}$ & $\begin{array}{l}\text { Upper- } \\
\text { Bound }\end{array}$ \\
\hline $\begin{array}{l}\text { (1) Marriage to circumcised spouse or spouses only } \\
+ \text { age + age-squared }\end{array}$ & .092 & .077 & .015 & -.017 & .047 \\
\hline (2) + Balaka resident & .049 & .092 & -.043 & -.075 & -.011 \\
\hline (3) + Balaka + socio-economic characteristics & .050 & .091 & -.041 & -.073 & -.009 \\
\hline $\begin{array}{l}\text { (4) }+ \text { Balaka + socio-economic characteristics }+ \\
\text { married }>\text { once }+ \text { absence of spousal co-residence }\end{array}$ & .051 & .072 & -.022 & -.052 & .009 \\
\hline $\begin{array}{l}\text { Panel B. In Balaka, full model with varied } \\
\text { spousal circumcision and marriage histories. }\end{array}$ & $\begin{array}{c}\text { Married >1 } \\
(=1) \& \\
\text { Absent } \\
\text { Spouse } \\
(=1)\end{array}$ & $\begin{array}{c}\text { Married >1 } \\
(=0) \& \\
\text { Absent } \\
\text { Spouse } \\
(=0) \\
\end{array}$ & Difference & $\begin{array}{l}\text { Lower- } \\
\text { Bound }\end{array}$ & $\begin{array}{l}\text { Upper- } \\
\text { Bound }\end{array}$ \\
\hline \multicolumn{6}{|l|}{ Model } \\
\hline (1) Circumcised spouse or spouses only $(=0)$ & .316 & .054 & .262 & .141 & .383 \\
\hline (2) Circumcised spouse or spouses only (=1) & .228 & .036 & 193 & .098 & .288 \\
\hline
\end{tabular}

Panel C. By district.

\begin{tabular}{lccccc}
\hline $\begin{array}{l}\text { Model: } \\
\text { (1) Circumcised spouse or spouses only + socio- } \\
\text { economics + age + age-squared }\end{array}$ & Balaka & $\begin{array}{c}\text { Mchinji \& } \\
\text { Rumphi }\end{array}$ & Difference & $\begin{array}{c}\text { Lower- } \\
\text { Bound }\end{array}$ & $\begin{array}{c}\text { Upper- } \\
\text { Bound }\end{array}$ \\
\cline { 2 - 6 } $\begin{array}{l}\text { Full model with varying scenarios of marriage history: } \\
\text { (2) married > once (=1), absent spouse (=1) }\end{array}$ & .101 & .051 & .049 & .008 & .091 \\
(3) married > once (=1), absent spouse (=0) & .290 & .165 & .125 & .030 & .221 \\
(4) married > once (=0), absent spouse (=1) & .162 & .085 & .076 & .012 & .140 \\
(5) married > once (=0), absent spouse $(=0)$ & .118 & .061 & .057 & .008 & .106 \\
\hline
\end{tabular}

Notes: Each probability is estimated with covariates set to their means, except where otherwise indicated. Significant differences using the delta method are in bold. 
To provide a rigorous understanding of the relative effects of spousal circumcision, marriage history, and district on HIV infection, we present results from models that relax the constraints imposed in Table 3, treating Balaka (Models $1-3$ ) and Mchinji \& Rumphi (Models $4-6$ ) samples separately. The results are shown in Table 5.

The estimates shown in Models 1 through 2 are consistent with Models 2 through 3 in Table 3. The effect of spousal circumcision remains significant and stable with the addition of socio-economic characteristics. This suggests the presence of an indirect, protective effect of male circumcision on female partners' lower risk of HIV infection - because circumcised men have a lower probability of HIV infection than uncircumcised men, women married to circumcised men also have a lower probability of HIV infection (Baeten et al. 2010). With the addition of multiple marriages and an absence of spousal co-residence in Model 3, the strength of the underlying circumcision coefficient is reduced substantially. To check for multicollinearity we measured the variance inflation factor (VIF) for all variables in each regression reported. All VIF values were 1.7 or lower, well below the value of 2.5 that typically raises concern. We again use predicted probabilities and the delta method to determine whether differences are statistically significant, and to determine how distinct configurations of marriage history and spousal circumcision are related to probability of HIV infection. The results are presented in Panel B in Table 4.

Holding age and socioeconomic measures constant, the average woman living in Balaka who has two different marriage scenarios that are characterized by an alteration of living arrangements - that is, a woman married more than once, who has ever experienced an absence of spousal co-residence - and who is married to an uncircumcised spouse, has a predicted probability of HIV infection of .316. For the average woman living in Balaka, who has only a single marriage and has never experienced an absence of spousal co-residence but whose spouse is uncircumcised, the predicted probability of HIV infection is dramatically lower, .051 (Table 4, Panel B, Model 1). The difference across marital history scenarios is also large and significant among women with circumcised spouses only, but the predicted probabilities are lower for women with circumcised spouses compared to those evermarried to a circumcised spouse.

Circumcision is not correlated with increased odds of HIV infection in Mchinji and Rumphi (Table 5, Models 4-6). The standard errors for the underlying coefficients are large and attributable to its relatively rare practice in these districts. Multiple marriages in Mchinji \& Rumphi increase a woman's odds of being infected with HIV ( $\mathrm{z}=3.62)$, as they did in Balaka ( $\mathrm{z}=2.91)$. An ever-absence of spousal co-residence is positively correlated with HIV infection in both panels, although the coefficient is not statistically significant in Mchinji \& Rumphi. 
Tests for the equality of predicted probabilities for varying marriage scenarios, by district, are presented in Panel C, Table 4. Varying the two binary measures (married more than once, ever an absence of spousal co-residence) produces four scenarios ((2) (5)). All of the models yield non-negligible differences between Balaka and Mchinji \& Rumphi, indicating that a residual effect of Balaka residence remains, irrespective of marriage scenario, and as was shown in Table $3 .{ }^{15}$ However, multiple marriages and absence of spousal co-residence are correlated with a much greater predicted probability of HIV infection in Balaka than in Mchinji \& Rumphi - a difference of .125 percentage points, Panel C (2), Table 4. Tests for an interaction between marital histories and district were not significant; in other words, the strength of the relations between multiple marriages, absence of spousal co-residence, and the probability of being HIV positive do not differ appreciably across districts. ${ }^{16}$ Therefore the difference in the probabilities shown in Panel $\mathrm{C}$ is attributable to a greater fraction of multiple marriages and absence of spousal co-residence in Balaka compared to the other districts, as shown in Table 2.

Table 5: Women's likelihood of being HIV positive, by spousal circumcision, models unconstrained by region

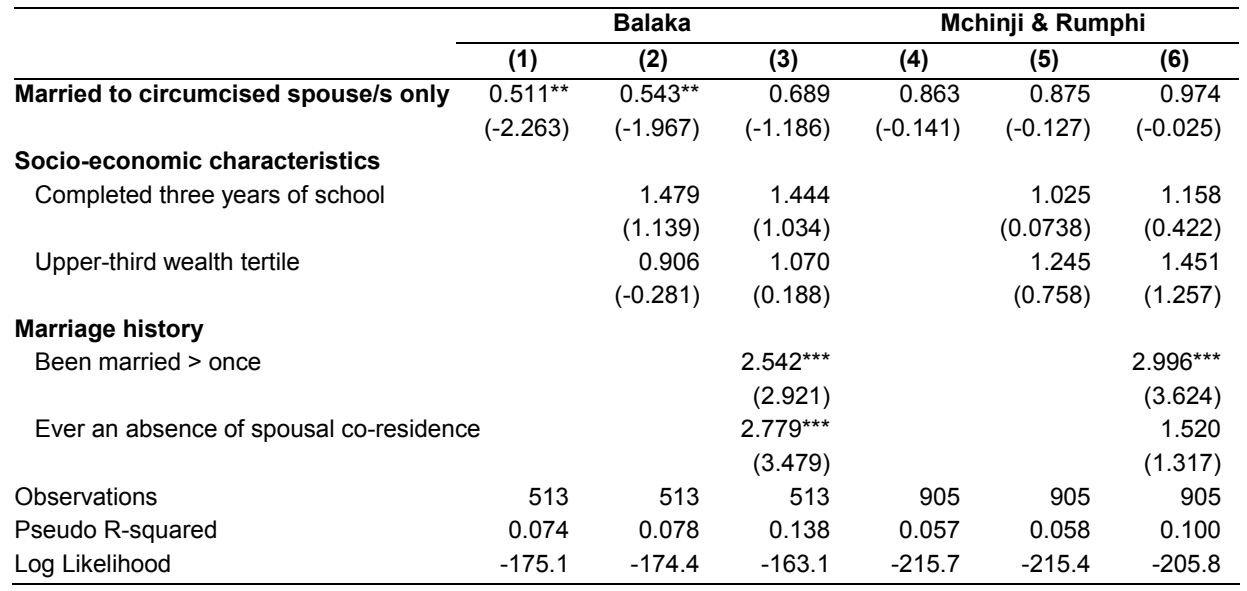

Robust $z$ statistics in parentheses.

${ }^{\star * \star} p<0.01,{ }^{* \star} p<0.05$

Notes: All models control for age and age-squared. The variables "circumcised spouse/s only" and "ever an absence of spousal coresidence" refer to current or former marriages. Respondents ever married to an uncircumcised spouse are coded '0,' regardless of whether their current spouse is circumcised. Respondents reporting never an absence of spousal co-residence are coded ' 0 .'

${ }^{15}$ Including polygynous unions does not explain the difference between Balaka and Mchinji \& Rumphi, and we therefore omitted this measure from the results presented.

${ }^{16}$ Not shown: results available from the first author upon request. 
A note of caution: we cannot determine with certainty whether attrition influences the key correlations in these empirical models. However, we were able to estimate basic models among a sample of women that eventually attrite from the survey, and use these results to determine whether these women differ from the women who do not attrite. The results (not shown) provide no evidence that attrition has led us to overstate the strength of the relationship between the circumcision status of women's spouses and the chances of being HIV positive. ${ }^{17}$

\section{Discussion and conclusions}

An apparent conundrum motivated this research: compared to districts in Central and Northern Malawi, HIV prevalence is highest in the southern district of Balaka where men are commonly circumcised. Table 1 showed that although $80 \%$ of the MDICP sample of men in Balaka reported being circumcised, over $11 \%$ of female Balaka residents were infected with HIV. In the northern district of Rumphi and the central district of Mchinji few men are circumcised, yet there HIV prevalence is significantly lower.

Our inquiry into this puzzle led us to several findings. First and foremost, among women who have ever married in Balaka, those with a history of marriage to circumcised spouses have lower odds of HIV infection compared to women who were ever married to a spouse not circumcised. This relation does not appear to be influenced by age, wealth, or education. Second, the strength of this seeming protective effect is weakened in the presence of a specific marital history: among Balaka women with circumcised spouses, those with multiple marriages and spouses who have ever resided in other locations have a higher probability of HIV infection than do those with single marriages and who have only coresided with their spouses. Third, in all three districts the effects of multiple marriages and absence of spousal co-residence on the probability of HIV infection were strong. Tests for interaction effects between these measures and district were insignificant. Therefore, we cannot conclude that having a second (or third) marriage is any "riskier" for women in Central and Northern Malawi than it is in Southern Malawi. Compared to the women of Mchinji and the women of Rumphi, however, in Balaka significantly more women have experienced marital turnover and

\footnotetext{
${ }^{17}$ Although the circumcision status of spouses was not asked in waves prior to 2004, we proxy by using ethnic group, and assume that being Yao is roughly equivalent to being married to a husband who is circumcised. We estimate a model of individual predictors of attrition among women between the MDICP's first (1998), second (2001), and third (2004) waves. Within Balaka, and net of age, Yao women were significantly less likely to leave the sample between 1998 and 2001 and between 2001 and 2004. Yao women within Balaka were also less likely to be deceased in 2004. These results indicate that, if anything, the strength of the relationship between spousal circumcision and women's HIV status is understated.
} 
have lived apart from a current or former spouse while married. One-fifth of women in Balaka reported having or having had a spouse who "stayed elsewhere," $45 \%$ had been married more than once, and 15\% had been married more than twice (Table 2). Thus, what appears to be contributing to the higher HIV levels in Balaka's recent past is that there, and compared to the other districts in this study, a greater fraction of the population has been married multiple times and has lived apart from their spouses. Although the above findings cannot definitively explain the uneven distribution of HIV in Malawi, taken together they shed light. Some qualifications follow.

Our data do not enable us to pinpoint the time at which a woman becomes infected with HIV relative to her marital history. Although we found that a woman with multiple marriages has increased odds of HIV infection, we do not know whether she became infected in her first marriage, her second marriage, in-between her two marriages, or even prior to her first marriage. Ideally, we would have access to data that would enable us to estimate the precise timing of infection as it occurs within individual marital trajectories, but the cross-sectional nature of the data we use from the MDICP does not. Our study is valuable in other ways, however, particularly in its use of the rich set of marital histories, including rarer measures, such as the measure of the absence of spousal co-residence.

Other studies that have used the MDICP data suggest that Malawian women use divorce strategically to avoid infection by a spouse perceived or known to have engaged in risky behavior, which suggests that a fair number of new infections occurs prior to second marriages. If worries about future or current infection are higher in Balaka than in Mchinji and in Rumphi, and women are responding to perceived risk by divorcing their spouses in search of "safer" ones (Smith and Watkins 2005), then the greater fraction of higher-order marriages found in Balaka could be generated from a greater fraction of the population responding to perceived risk by way of divorce and remarriage, often to spouses thought to be safer. Results from other studies suggest that this does not appear to be the case, however. Although women and men overestimate their subjective probability of infection, the degree of worry generally does not differ by district (Anglewicz and Kohler 2009; Smith and Watkins 2005).

As discussed previously, divorce and remarriage in Southern Malawi were common long before the advent of AIDS (Reniers 2003), largely an outcome of the coupling of matrilineal and matrilocal forms of social organization practiced by the Yao-, Chewa-, and Lomwe-speaking groups residing there (Kaler 2001; Peters 1997; see also Ferguson 1999 for Zambia); combined, these forms facilitate a strong bond among kin in the matriline that often temper or even supplant the spousal bond. Men in matrilineal-matrilocal communities have obligations to female kin in their home villages, requiring frequent visits and sometimes extended stays. Historically, femaleheaded households are therefore not uncommon (Vaughan 1983). Even when 
matrilineality/matrilocality is not strictly adhered to today, the historical tendency toward this practice in Balaka likely set the ground for a continued relative ease of divorce and remarriage in the era of AIDS. ${ }^{18}$ It is possible that the common occurrence of divorce and remarriage contributed to the spread of HIV in the early stages of Balaka's epidemic by way of a region-specific sexual network constellation. The persistent regularity of divorce and remarriage may help sustain the epidemic, in spite of the practice of male circumcision.

Among the women of Balaka, having experienced an absence of spousal coresidence was correlated with increased odds of HIV infection. This relation was also positive in Mchinji and Rumphi, but the effect was not significant. Most spousal separation in Malawi is labor-related: over half $(59 \%)$ of the sample attributed their spousal separation to husbands' labor. An additional quarter (26\%) reported their spouses were with another wife; the remainder reported another reason, such as visiting relatives. ${ }^{19}$ Not only are Balaka women more likely to have experienced an absence of spousal co-residence, but when experienced, reasons are more likely to be labor-related, compared to those in the Mchinji and Rumphi (63\% versus 55\%, respectively), a statistically significant difference at the .05 level based on a t-test equality of means. Data from the sample of men on geographic mobility provide results consistent with the women's reports. The men of Balaka have increased odds of having ever lived in a Malawian city, having ever been away for six months in their lifetimes, having been away for at least one month during the prior year, and having ever lived in South Africa (Figure 1).

Following Malawi's change from an autocratic government to a multi-party democracy in 1994 and its simultaneous relative economic liberalization, new opportunities for enterprise opened up in Malawi's urban areas, and internal migration rates rose. There are fewer agricultural-related employment opportunities in Malawi's Southern Region than there are in the Northern and Central Regions, and Southern Malawi also has a disproportionate number of very poor villages, contributing to Balaka's relatively higher levels of labor-related migration (Malawi Second Integrated Household Survey (IHS-2)). As important, though, was the view held among the Yao that entrepreneurial activities in the city townships became newly available around the time of Malawi's political transition in 1994, as reflected in Figure 1, and as witnessed

\footnotetext{
18 In Mchinji, the predominant Chewa practice more blended forms of marriage and social life that incorporate patrilineality and patrilocality, and is attributable to their proximity to the patrilineal and patrilocal Ngoni (Phiri 1983).

${ }^{19}$ Reniers and Tfailey (2008) showed that women in polygynous unions have a higher probability of HIV infection. Our analyses find this to be the case only for women with single marriages (not shown), a finding we are cautious to give weight to because of our concerns over bias from selection effects. In the models presented in Tables 3 through 5, adding polygynous union variables did not alter the substantive findings. As with other specification tests that did not yield significant results, we omitted these measures, but they are available from the first author upon request.
} 
by a relatively greater number of in-migrant Yao residents in an urban township in Malawi's capital of Lilongwe. This is to some extent due to the fact that Malawi's first post-1994 President, Bakili Muluzi, is Yao (Englund 2002b:138).

Figure 1: Balaka men's geographic mobility compared to men in Mchinji \& Rumphi, odds ratios

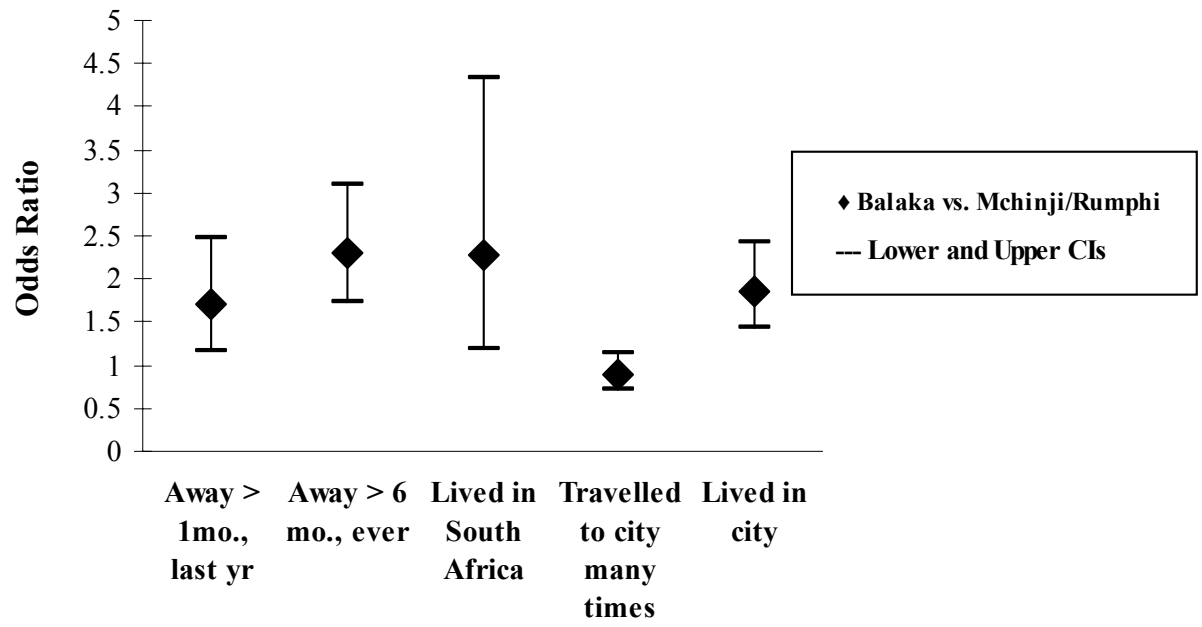

Notes: These models controlled for individual-level age, education, and wealth.

Male villagers who reside in urban locales maintain strong affiliations with native villages, and return home regularly to bear gifts, to pay remittances, or to display evidence of a successful transition to city life, however small (or even contrived) that success may be. Men with two homes, or those with a primary urban residence who have not quite rescinded their rural residence, arguably have greater opportunities to engage in simultaneous sexual relationships, whether they are with a second (informal) wife, an extra-marital partner, or, if not married, with a second, non-marital partner (Chirwa 1997). Several studies in Southern Africa have suggested that women, too, engage in extramarital romances or have casual partners (Hunter 2007; Johnson et al. 2009; Lurie 2006).

For future research, two additional hypotheses for the relatively higher HIV levels in Balaka are worth considering. The first is variation in opportunity costs and access to health clinics. Women and men in Balaka have poorer access to health care (Malawi 
Second Integrated Household Survey, 2005), and may have higher rates of STI infection, which in turn has the potential to increase the transmissibility of HIV through unprotected intercourse. Second, a recent modeling study (Clark and Eaton 2008) suggest that the timing of infection over the life course is an important determinant of overall prevalence and overall incidence rates in a population-becoming infected at younger ages means a more rapid spread of HIV. In Balaka women marry and remarry at earlier ages than in Mchinji and in Rumphi (Reniers 2003). This resonates with Magruder's argument (2010) that in South Africa the rate of partner change early in life has contributed to the country's high levels of HIV (although in the case of South Africa the partner turnover occurs prior to, or instead of, marriage).

Clark and Eaton (2008) conducted a series of simulations to estimate the impact of various male circumcision interventions (for instance, by age and amount of population covered) in reducing HIV prevalence and incidence in a population. They find that, for a population at risk of infection to receive the most benefit from male circumcision interventions, the optimal point at which to intervene is just before men become sexually active. They note, "in terms of equity, it appears that age rather than sex is the real dimension along which there is likely to be significant inequity with male circumcision interventions" (p. 21; emphasis in the original). Male circumcision delays infection, and by implementing the procedure among young men, risk of infection is pushed to older ages, which in turns reduces overall incidence in the population (Clark and Eaton 2008). They conclude that male circumcision alone is unlikely to be sufficient to eradicate HIV, but that it will likely reduce HIV prevalence and incidence in a population.

In our data the circumcision status of husbands did not fully explain the distribution of HIV infection found among wives, pointing to concerns over the longterm population effects of male circumcision in HIV epidemics (Garenne 2008). Indeed, a significant amount of the difference in HIV prevalence across district was explained by what appears to be specific to Balaka, as marital turnover-high rates of divorce and remarriage - and periods of spousal separation due to historical and economic factors appear to make key contributions. Critically, however, these findings should not be interpreted to mean that the protective benefits of male circumcision found in other countries are inapplicable in Malawi- our results from Balaka directly challenge any such notion. Our simulations suggest that were a greater fraction of men uncircumcised, HIV prevalence in the district would be even higher. 


\section{Acknowledgments}

We have benefitted from comments on earlier drafts and discussion about this paper from Jimi Adams, Kathleen Beegle, Abdullah Chilungo, Agnes Chimbiri, Jeff Eaton, Monica Grant, Margot Jackson, Dennis Hogan, Hans-Peter Kohler, J. Scott Long, Pauline Peters, Georges Reniers, Kelley Smith, Ann Swidler, Susan Watkins, and Michael White. Remaining errors are our own. The MDICP is supported by grants from the Rockefeller Foundation; NICHD (R01-HD4173, R01 HD372-276); NIA (AG1236S3), and the Center for AIDS Research and the Center on the Demography of Aging at the University of Pennsylvania. 


\section{References}

Ali, M.M., Cleland, J., and Shah, I.H. (2004). Condom use within marriage: A neglected HIV intervention. Bulletin of the World Health Organization 82(3): 180-186. doi:10.1590/S0042-96862004000300007.

Allen, S., Lindan, C., Serufilira, A., Van de Perre, P., Rundle, A.C., Nsengumuremyi, F., Carael, M., Schwalbe, J., and Hulley, S. (1991). Human immunodeficiency virus infection in urban Rwanda: Demographic and behavioral correlates in a representative sample of childbearing women. Journal of the American Medical Association 266(12): 1657-1663. doi:10.1001/jama.1991.03470120059033.

Allison, P.D. (1999). Comparing logit and probit coefficients across groups. Sociological Methods \& Research 28(2): 186-208. doi:10.1177/ 0049124199028002003.

Anglewicz, P. (2011). Migration, marital change, and HIV infection in Malawi. Demography. (forthcoming). doi:10.1007/s13524-011-0072-x.

Anglewicz, P. and Kohler, H.-P. (2009). Overestimating HIV infection: The construction and accuracy of subjective probabilities of HIV infection in rural Malawi. Demographic Research 20(6): 65-96. doi:10.4054/DemRes.2009.20.6.

Arrive, E., Newell, M.-L., Ekouevi, D.K., Chaix, M.-L., Thiebaut, R., Masquelier, B., Leroy, V., Perre, P.V.D., Rouzioux, C., Dabis, F., and for the Ghent Group on HIV in Women and Children. (2007). Prevalence of resistance to nevirapine in mothers and children after single-dose exposure to prevent vertical transmission of HIV-1: A meta-analysis. International Journal of Epidemiology 36(5): 10091021. doi:10.1093/ije/dym104.

Auvert, B., Taljaard, D., Lagarde, E., Sobngwi-Tambekou, J., Sitta, R., and Puren, A. (2005). Randomized, controlled intervention trial of male circumcision for reduction of HIV infection risk: The ANRS 1265 Trial. PLoS Medicine 2(11): 1112-1122. doi:10.1371/journal.pmed.0020298.

Baeten, J.M., Donnell, D., Kapiga, S.H., Ronald, A., John-Stewart, G., Inambao, M., Manongi, R., Vwalika, B., and Celum, C. (2010). Male circumcision and risk of male-to-female HIV-1 transmission: A multinational prospective study in African HIV-1-serodiscordant couples. AIDS 24(5): 737-744. doi:10.1097/QAD. 0b013e32833616e 0 .

Bailey, R.C., Moses, S., Parker, C.B., Agot, K., Maclean, I., Krieger, J.N., Williams, C.F.M., Campbell, R.T., and Ndinya-Achola, J.O. (2007). Male circumcision for 
HIV prevention in young men in Kisumu, Kenya: A randomised controlled trial. The Lancet 369(9562): 643-656. doi:10.1016/S0140-6736(07)60312-2.

Bärnighausen, T., Hosegood, V., Timaeus, I.M., and Newell, M.L. (2007). The socioeconomic determinants of HIV incidence: Evidence from a longitudinal, population-based study in rural South Africa. AIDS 21(Suppl. 7): S29-S38. doi:10.1097/01.aids.0000300533.59483.95.

Bignami-Van Assche, S., Lei-Wie, C., Hoffman, I., Kohler, H.-P., Reniers, G., and Smith, K. (2004). Protocol for biomarker testing in the 2004 Malawi Diffusion and Ideational Change Project. Philadelphia: University of Pennsylvania (SNP Working Paper No.7).

Boeke, C.E. and Jackson, J.B. (2008). Estimate of infant HIV-free survival at 6 to 8 Weeks of age due to maternal antiretroviral prophylaxis in sub-Saharan Africa, 2004-2005. Journal of the International Association of Physicians in AIDS Care 7(3): 133-140. doi:10.1177/1545109708318517.

Boerma, J., Gregson, S., Nyamukapa, C., and Urassa, M. (2003). Understanding the uneven spread of HIV within Africa: Comparative study of biologic, behavioral, and contextual factors in rural populations in Tanzania and Zimbabwe. Sexually Transmitted Diseases 30(10): 779-787. doi:10.1097/01.OLQ.0000078820.628 97.A6.

Boerma, J.T., Urassa, M., Nnko, S., Ng'weshemi, J., Isingo, R., Zaba, B., and Mwaluko, G. (2002). Sociodemographic context of the AIDS epidemic in a rural area in Tanzania with a focus on people's mobility and marriage. Sexually Transmitted Infections 78(Suppl. 1): i97-i105. doi:10.1136/sti.78.suppl_1.i97.

Boerma, J.T. and Weir, S.S. (2005). Integrating demographic and epidemiological approaches to research on HIV/AIDS: The proximate determinants framework. The Journal of Infectious Diseases 191(Suppl. 1): S61-S67. doi:10.1086/425282.

Boileau, C., Clark, S., Bignami-Van Assche, S., Poulin, M., Reniers, G., Watkins, S.C., Kohler, H.-P., and Heymann, S.J. (2009). Sexual and marital trajectories and HIV infection among ever-married women in rural Malawi. Sexually Transmitted Infections 85(Suppl. 1): i27-i33. doi:10.1136/sti.2008.033969.

Bongaarts, J. (2007). Late marriage and the HIV - epidemic in sub-Saharan Africa. Population Studies 61(1): 73-83. doi:10.1080/00324720601048343.

Caraël, M. and Holmes, K.K. (2001). Dynamics of HIV epidemics in sub-Saharan Africa: Introduction. AIDS 15(Suppl. 4): S1-S4. doi:10.1097/00002030-2001 08004-00001. 
Chimbiri, A.M. (2007). The condom is an 'intruder' in marriage: Evidence from rural Malawi. Social Science \& Medicine 64(5): 1102-1115. doi:10.1016/j.socscimed. 2006.10.012.

Chirwa, W.C. (1997). Migrant labour, sexual networking and multi-partnered sex in Malawi. Health Transition Review 7(Suppl. 3): 5-15.

Chomba, E., Allen, S., Kanweka, W., Tichacek, A., Cox, G., Shutes, E., Zulu, I., Kancheya, N., Sinkala, M., Stephenson, R., and Haworth, A. (2008). Evolution of couples' voluntary counseling and testing for HIV in Lusaka, Zambia. Journal of Acquired Immune Deficiency Syndromes 47(1): 108-115. doi:10.1097/QAI.0b013e31815b2d67.

Clark, S. (2004). Early marriage and HIV risks in sub-Saharan Africa. Studies in Family Planning 35(3): 149-160. doi:10.1111/j.1728-4465.2004.00019.x.

Clark, S., Poulin, M., and Kohler, H.-P. (2009). Marriage aspirations, sexual behaviors, and HIV/AIDS in rural Malawi. Journal of Marriage and the Family 71(2): 396416. doi:10.1111/j.1741-3737.2009.00607.x.

Clark, S.J. and Eaton, J.E. (2008). Demographic consequences of HIV epidemics and effects of different male circumcision intervention designs: Suggestive findings from microsimulation. University of Washington. (working paper; No. 85).

Coffee, M., Lurie, M.N., and Garnett, G.P. (2007). Modelling the impact of migration on the HIV epidemic in South Africa. AIDS 21(3): 343-350. doi:10.1097/ QAD.0b013e328011dac9.

De Walque, D. (2007). Sero-discordant couples in five African countries: Implications for prevention strategies. Population and Development Review 33(3): 501-523. doi:10.1111/j.1728-4457.2007.00182.x.

Dickson, K. (2010). Male circumcision for HIV prevention: Progress in scale-up. Paper presented at the symposium session 18: New strategies for a changing epidemic. Seventeenth Conference on Retroviruses and Opportunistic Infections, San Francisco.

Doyle, S.M., Kahn, J.G., Hosang, N., and Carroll, P.R. (2010). The impact of male circumcision on HIV transmission. The Journal of Urology 183(1): 21-26. doi:10.1016/j.juro.2009.09.030.

Dunkle, K.L., Stephenson, R., Karita, E., Chomba, E., Kayitenkore, K., Vwalika, C., Greenberg, L., and Allen, S. (2008). New heterosexually transmitted HIV infections in married or cohabiting couples in urban Zambia and Rwanda: An 
analysis of survey and clinical data. The Lancet 371(9631): 2183-2191. doi:10.1016/S0140-6736(08)60953-8.

Englund, H. (2002a). Ethnography after globalism: Migration and emplacement in Malawi. American Ethnologist 29(2): 261-286. doi:10.1525/ae.2002.29.2.261.

Englund, H. (2002b). The village in the city, the city in the village: Migrants in Lilongwe. Journal of Southern African Studies 28(1): 137-154. doi:10.1080/ 03057070120117015.

Ferguson, J. (1999). Expectations of modernity: myths and meanings of urban life on the Zambian Copperbelt. Berkeley, California: University of California Press.

Fortson, J.G. (2008). The gradient in sub-Saharan Africa: Socioeconomic status and HIV/AIDS. Demography 45(2): 303-322. doi:10.1353/dem.0.0006.

Fylkesnes, K., Musonda, R.M., Kasumba, K., Ndhlovu, Z., Mluanda, F., Kaetano, L., and Chipaila, C.C. (1997). The HIV epidemic in Zambia: Socio-demographic prevalence patterns and indications of trends among childbearing women. AIDS 11(3): 339-345. doi:10.1097/00002030-199703110-00012.

Garenne, M. (2008). Long-term population effect of male circumcision in generalised HIV epidemics in sub-Saharan Africa. African Journal of AIDS Research 7(1): 1-8. doi:10.2989/AJAR.2008.7.1.1.429.

Gillespie, S., Kadiyala, S., and Greener, R. (2007). Is poverty or wealth driving HIV transmission? AIDS 21(Suppl. 7): S5-S16. doi:10.1097/01.aids.0000300531. 74730.72 .

Glynn, J.R., Carael, M., Auvert, B., Kahindo, M., Chege, J., Musonda, R., Kaona, F., and Buvé, A. (2001a). Why do young women have a much higher prevalence of HIV than young men? A study in Kisumu, Kenya and Ndola, Zambia. AIDS 15(Suppl. 4): S51-S60. doi:10.1097/00002030-200108004-00006.

Glynn, J.R., Caraël, M., Buvé, A., Musonda, R.M., and Kahindo, M. (2003). HIV risk in relation to marriage in areas with high prevalence of HIV infection. Journal of Acquired Immune Deficiency Syndromes 33(4): 526-535. doi:10.1097/0012633 4-200308010-00015.

Glynn, J.R., Pönnighaus, J., Crampin, A.C., Sibande, F., Sichali, L., Nkhosa, P., Broadbent, P., and Fine, P.E.M. (2001b). The development of the HIV epidemic in Karonga District, Malawi. AIDS 15(15): 2025-2029. doi:10.1097/00002030200110190-00016. 
Gray, R.H., Kigozi, G., Serwadda, D., Makumbi, F., Watya, S., Nalugoda, F., Kiwanuka, N., Moulton, L.H., Chaudhary, M.A., Chen, M.Z., Sewankambo, N.K., Wabwire-Mangen, F., Bacon, M.C., Williams, C.F.M., Opendi, P., Reynolds, S.J., Laeyendecker, O., Quinn, T.C., and Wawer, M.J. (2007). Male circumcision for HIV prevention in men in Rakai, Uganda: A randomised trial. The Lancet 369(9562): 657-666. doi:10.1016/S0140-6736(07)60313-4.

Gray, R.H., Kiwanuka, N., Quinn, T.C., Sewankambo, N.K., Serwadda, D., Mangen, F.W., Lutalo, T., Nalugoda, F., Kelly, R., Meehan, M., Chen, M.Z., Li, C., and Wawer, M.J. (2000). Male circumcision and HIV acquisition and transmission: Cohort studies in Rakai, Uganda. AIDS 14(15): 2371-2381. doi:10.1097/ 00002030-200010200-00019.

Gregson, S., Nyamukapa, C.A., Garnett, G.P., Mason, P.R., Zhuwau, T., Caraël, M., Chandiwana, S.K., and Anderson, R.M. (2002). Sexual mixing patterns and sexdifferentials in teenage exposure to HIV infection in rural Zimbabwe. The Lancet 359(9321): 1896-1903. doi:10.1016/S0140-6736(02)08780-9.

Gregson, S., Waddell, H., and Chandiwana, S.K. (2001). School education and HIV control in Sub-Saharan Africa: From harmony to discord. Journal of International Development 13(4): 467-485. doi:10.1002/jid.798.

Hargreaves, J.R., Bonell, C.P., Morison, L.A., Kim, J.C., Phetla, G., Porter, J.D.H., Watts, C., and Pronyk, P.M. (2007). Explaining continued high HIV prevalence in South Africa: Socioeconomic factors, HIV incidence and sexual behaviour change among a rural cohort, 2001-2004. AIDS 21(Suppl.7): S39-S48. doi:10.1097/01.aids.0000300534.97601.d6.

Hargreaves, J.R. and Glynn, J.R. (2002). Educational attainment and HIV-1 infection in developing countries: A systematic review. Tropical Medicine and International Health 7(6): 489-498. doi:10.1046/j.1365-3156.2002.00889.x.

Helleringer, S., Kohler, H.-P., and Chimbiri, A.M. (2007). Characteristics of external/bridge relationships by partner type and location where sexual relationship took place. AIDS 21(18): 2560-2561. doi:10.1097/QAD.0b013e 3282fl12bd.

Hirsch, J.S., Wardlow, H., Smith, D.J., Phinney, H.M., Parikh, S., and Nathanson, C.A. (2009). The Secret: Love, Marriage, and HIV. Nashville, TN: Vanderbilt University Press.

Hunter, D.J., Maggwa, B.N., Mati, J.K.G., Tukei, P.M., and Mbugua, S. (1994). Sexual behavior, sexually transmitted diseases, male circumcision and risk of HIV 
infection among women in Nairobi, Kenya. AIDS 8(1): 93-99. doi:10.1097/ 00002030-199401000-00014.

Hunter, M. (2007). The changing political economy of sex in South Africa: The significance of unemployment and inequalities to the scale of the AIDS pandemic. Social Science \& Medicine 64(3): 689-700. doi:10.1016/j.socscimed. 2006.09.015.

Iliffe, J. (2006). A history of the African AIDS epidemic. Oxford: James Currey.

Johnson, L., Dorrington, R., Bradshaw, D., Pillay-Van Wyk, V., and Rehle, T. (2009). Sexual behaviour patterns in South Africa and their association with the spread of HIV: Insights from a mathematical model. Demographic Research 21(11): 289-340. doi:10.4054/DemRes.2009.21.11.

Kaler, A. (2001). Many divorces and many spinsters: Marriage as an invented tradition in Southern Malawi, 1946-1999. Journal of Family History 26(4): 529-556. doi:10.1177/036319900102600405.

Kapiga, S.H., Lyamuya, E.F., Lwihula, G.K., and Hunter, D.J. (1998). The incidence of HIV infection among women using family planning methods in Dar es Salaam, Tanzania. AIDS 12(1): 75-84. doi:10.1097/00002030-199801000-00009.

Karim, S.S.A. (2009). Commentary: Spatial clustering of HIV infection: providing clues for effective HIV prevention. International Journal of Epidemiology 38(4): 1016-1017. doi:10.1093/ije/dyp201.

Kelly, R.J., Gray, R.H., Sewankambo, N.K., Serwadda, D., Wabwire-Mangen, F., Lutalo, T., and Wawer, M.J. (2003). Age differences in sexual partners and risk of HIV-1 infection in rural Uganda. JAIDS Journal of Acquired Immune Deficiency Syndromes 32(4): 446-451. doi:10.1097/00126334-20030401000016.

Kretzschmar, M. and Morris, M. (1996). Measures of concurrency in networks and the spread of infectious disease. Mathematical Biosciences 133(2): 165-195. doi:10.1016/0025-5564(95)00093-3.

Kumwenda, N.I., Kumwenda, J., Kafulafula, G., Makanani, B., Taulo, F., Nkhoma, C., Li, Q., and Taha, T.E. (2008). HIV-1 incidence among women of reproductive age in Malawi. International Journal of STD \& AIDS 19(5): 339-341. doi:10.1258/ijsa.2007.007165. 
Long, J.S. (2009). Group comparisons in logit and probit using predicted probabilities. (Working paper draft 2009-06-05). http://www.indiana.edu/ jslsoc/research groupdif.htm.

Lopman, B.A., Nyamukapa, C., Hallett, T.B., Mushati, P., Preez, N., Kurwa, F., Wambe, M., and Gregson, S. (2009). Role of widows in the heterosexual transmission of HIV in Manicaland, Zimbabwe, 1998-2003. Sexually Transmitted Infections 85: i41-i48. doi:10.1136/sti.2008.033043.

Lurie, M.N. (2005). Population movement and the spread of HIV in Southern Africa. In: Karim, S.S.A. and Karim, Q.A. (eds.). HIV/AIDS in South Africa. New York: Cambridge University Press: 298-312.

Lurie, M.N. (2006). The epidemiology of migration and HIV/AIDS in South Africa. Journal of Ethnic and Migration Studies 32(4): 649-666. doi:10.1080/1369 1830600610056.

Lurie, M.N., Williams, B.G., Zuma, K., Mkaya-Mwamburi, D., Garnett, G.P., Sturm, A.W., Sweat, M.D., Gittelsohn, J., and Karim, S.S.A. (2003a). The impact of migration on HIV-1 transmission in South Africa. Sexually Transmitted Diseases 30(2): 149-156. doi:10.1097/00007435-200302000-00011.

Lurie, M.N., Williams, B.G., Zuma, K., Mkaya-Mwamburi, D., Garnett, G.P., Sweat, M.D., Gittelsohn, J., and Karim, S.S.A. (2003b). Who infects whom? HIV-1 concordance and discordance among migrant and non-migrant couples in South Africa. AIDS 17(15): 2245-2252. doi:10.1097/00002030-200310170-00013

Magruder, J. (2010). Marital shopping and epidemic AIDS. Berkeley: Department of Economics, University of California. (Unpublished working paper).

Malawi Demographic and Health Survey (MDHS). (2005). [electronic resource]. Calverton, Maryland, USA: National Statistical Office [Malawi] and Macro International, Inc. http://www.measuredhs.com/.

Malawi Second Integrated Household Survey (IHS-2). (2005). [electronic resource]. http://siteresources.worldbank.org/INTLSMS/Resources/33589861181743055198/3877319-1181928149600/IHS2_Basic_Information2.pdf

Mishra, V., Bignami-Van Assche, S., Greener, R., Vaessen, M., Hong, R., Ghys, P.D., Boerma, J., Van Assche, A., Khan, S., and Rutstein, S. (2007). HIV infection does not disproportionately affect the poorer in sub-Saharan Africa. AIDS 21(Suppl.7): S17-S28. doi:10.1097/01.aids.0000300532.51860.2a. 
Mitchell, J.C. (1951). An outline of the social structure of Malemia area. The Nyasaland Journal 4(2): 15-47.

Mitchell, J.C. (1956). The Yao village: A study in the social structure of a Nyasaland tribe. Manchester: Manchester University Press.

Moody, J. (2002). The importance of relationship timing for diffusion. Social Forces 81(1): 25-56. doi:10.1353/sof.2002.0056.

Morris, M. and Kretzschmar, M. (1995). Concurrent partnerships and transmission dynamics in networks. Social Networks 17(3-4): 299-318. doi:10.1016/03788733(95)00268-S.

Morris, M. and Kretzschmar, M. (1997). Concurrent partnerships and the spread of HIV. AIDS 11(5): 641-648. doi:10.1097/00002030-199705000-00012.

Morris, M. and Kretzschmar, M. (2000). A microsimulation study of the effect of concurrent partnerships on the spread of HIV in Uganda. Mathematical Population Studies 8(2): 109-133. doi:10.1080/08898480009525478.

Morris, M., Kurth, A.E., Hamilton, D.T., Moody, J., and Wakefield, S. (2009). Concurrent partnerships and HIV prevalence disparities by race: Linking science and public health practice. American Journal of Public Health 99(6): 1023-1031. doi:10.2105/AJPH.2008.147835.

Obare, F., Fleming, P., Anglewicz, P., Thornton, R., Martinson, F., Kapatuka, A., Poulin, M., Watkins, S.C., and Kohler, H.-P. (2009). Acceptance of repeat population-based voluntary counseling and testing for HIV and sociodemographic variations in HIV incidence in rural Malawi. Sexually Transmitted Infections 85(2): 139-144. doi:10.1136/sti.2008.030320.

Painter, T.M., Diaby, K.L., Matia, D.M., Lin, L.S., Sibailly, T.S., Kouassi, M.K., Ekpini, E.R., Roels, T.H., and Wiktor, S.Z. (2007). Faithfulness to partners: A means to prevent HIV infection, a source of HIV infection risks, or both? A qualitative study of women's experiences in Abidjan, Côte d'Ivoire. African Journal of AIDS Research 6(1): 25-31. doi:10.2989/16085900709490396.

Parikh, S.A. (2007). The political economy of marriage and HIV: The ABC approach, "safe" infidelity, and managing moral risk in Uganda. American Journal of Public Health 97(7): 1198-1208. doi:10.2105/AJPH.2006.088682.

Peters, P.E. (1997). Against the odds: Matriliny, land and gender in the Shire Highlands of Malawi. Critique of Anthropology 17(2): 189-210. doi:10.1177/ 0308275 X9701700205. 
Phiri, K.M. (1983). Some changes in the matrilineal family system among the Chewa of Malawi since the Nineteenth century. The Journal of African History 24(2): 257274. doi:10.1017/S0021853700021976.

Poulin, M. (2011). The heart of the deal: Individualism, collectivism, and human rights in a new democracy. University of North Texas. (Mimeo).

Poulin, M. and Watkins, S.C. (2011). Men with money and the persistence of AIDS in sub-Saharan Africa. University of North Texas. (Mimeo).

Quigley, M.A., Morgan, D., Malamba, S.S., Mayanja, B., Okongo, M.J., Carpenter, L.M., and Whitworth, J.A. (2000). Case-control study of risk factors for incident HIV infection in rural Uganda. Journal of Acquired Immune Deficiency Syndromes 23(5): 418-425. doi:10.1097/00042560-200004150-00009.

Reniers, G. (2003). Divorce and remarriage in rural Malawi. Demographic Research SC 1(6): 175-206. doi:10.4054/DemRes.2003.S1.6.

Reniers, G. (2008). Marital strategies for regulating exposure to HIV. Demography 45(2): 417-438. doi:10.1353/dem.0.0002.

Reniers, G. and Tfaily, R. (2008) Polygyny and HIV in Malawi. Demographic Research 19(53): 1811-1830. doi:10.4054/DemRes.2008.19.53.

Salathé, M. and Jones, J.H. (2010). Dynamics and control of diseases in networks with community structure. PLoS Computational Biology 6(4): e1000736. doi:10.137 1/journal.pcbi.1000736.

Shelton, J.D., Cassell, M.M., and Adetunji, J. (2005). Is poverty or wealth at the root of HIV? The Lancet 366(9491): 1057-1058. doi:10.1016/S0140-6736(05)67401-6.

Smith, D.J. (2007). Modern marriage, men's extramarital sex, and HIV risk in Southeastern Nigeria. American Journal of Public Health 97(6): 997-1005. doi:10.2105/AJPH.2006.088583.

Smith, K.P. and Watkins, S.C. (2005). Perceptions of risk and strategies for prevention: Responses to HIV/AIDS in rural Malawi. Social Science \& Medicine 60(3): 649660. doi:10.1016/j.socscimed.2004.06.009.

Taha, T.E., Kumwenda, N.I., Gibbons, A., Broadhead, R.L., Fiscus, S., Lema, V., Liomba, G., Nkhoma, C., Miotti, P.G., and Hoover, D.R. (2003). Short postexposure prophylaxis in newborn babies to reduce mother-to-child transmission of HIV-1: NVAZ randomised clinical trial. The Lancet 362(9391): 1171-1177. doi:10.1016/S0140-6736(03)14538-2. 
Tanser, F., Bärnighausen, T., Cooke, G.S., and Newell, M.-L. (2009). Localized spatial clustering of HIV infections in a widely disseminated rural South African epidemic. International Journal of Epidemiology 38(4): 1008-1016. doi:10.1093/ije/dyp148.

Tavory, I. and Swidler, A. (2009). Condom semiotics: Meaning and condom use in rural Malawi. American Sociological Review 74(2): 171-189. doi:10.1177/0003 12240907400201 .

Thornton, R.J. (2008). Unimagined community: sex, networks, and AIDS in Uganda and South Africa. Los Angeles: University of California Press.

Trask, S.A., Derdeyn, C.A., Fideli, U., Chen, Y., Meleth, S., Kasolo, F., Musonda, R., Hunter, E., Gao, F., Allen, S., and Hahn, B.H. (2002). Molecular epidemiology of human immunodeficiency virus type 1 transmission in a heterosexual cohort of discordant couples in Zambia. Journal of Virology 76(1): 397-405. doi:10.1128/JVI.76.1.397-405.2002.

Turner, A.N., Morrison, C.S., Padian, N.S., Kaufman, J.S., Salata, R.A., Chipato, T., Mmiro, F.A., Mugerwa, R.D., Behets, F.M., and Miller, W.C. (2007). Men's circumcision status and women's risk of HIV acquisition in Zimbabwe and Uganda. AIDS 21(13): 1779-1789. doi:10.1097/QAD.0b013e32827b144c.

Vail, L. and White, L. (1985). Tribalism in the political history of Malawi. In: Vail, L. (ed.). The creation of tribalism in southern Africa. Berkeley: University of California Press: 151-192.

Vaughan, M. (1983). Which family?: Problems in the reconstruction of the history of the family as an economic and cultural unit. Journal of African History 24(2): 275-283. doi:10.1017/S0021853700021988.

Von Hippel, P.T. (2007). Regression with missing Ys: An improved strategy for analyzing multiply imputed data. Sociological Methodology 37(1): 83-117. doi:10.1111/j.1467-9531.2007.00180.x.

Washington Post (2010). Malawi rules out circumcision for AIDS prevention. [electronic resource]. Washington, D.C.: Washington Post. http://www. washingtonpost.com/wp-dyn/content/story/2010/09/16/ST2010091603279.html

Watts, C.H. and May, R.M. (1992). The influence of concurrent partnerships on the dynamics of HIV/AIDS. Mathematical Biosciences 108(1): 89-104. doi:10.1016/0025-5564(92)90006-I. 
Wawer, M.J., Makumbi, F., Kigozi, G., Serwadda, D., Watya, S., Nalugoda, F., Buwembo, D., Ssempijja, V., Kiwanuka, N., and Moulton, L.H. (2009). Circumcision in HIV-infected men and its effect on HIV transmission to female partners in Rakai, Uganda: A randomised controlled trial. The Lancet 374(9685): 229-237. doi:10.1016/S0140-6736(09)60998-3.

Weinreb, A. (2002). Lateral and vertical intergenerational exchange in rural Malawi. Journal of Cross-Cultural Gerontology 17(2): 101-138. doi:10.1023/A:10158 34300553.

WHO/UNAIDS (2010). Progress in male circumcision scale-up: Country implementation and research update [electronic resource]. Geneva: World Health Organization and Joint United Nations Programme on HIV/AIDS. http://www.malecircumcision.org/documents/MC_country_June2010.pdf

World Bank and Government of Malawi (2007). Malawi poverty and vulnerability assessment: Investing in our future. Full Report. (Report No. 26546-MW).

Zuma, K., Lurie, M.N., Williams, B.G., Mkaya-Mwamburi, D., Garnett, G.P., and Sturm, A.W. (2005). Risk factors of sexually transmitted infections among migrant and non-migrant sexual partnerships from rural South Africa. Epidemiology and Infection 133(3): 421-428. doi:10.1017/S0950268804003607. 